\title{
A new Species of the Subterranean Amphipod genus Allocrangonyx (Gammaridae), with a Redescription of the genus and Remarks on its Zoogeography
}

\author{
By John R. Holsinger ${ }^{1,2)}$ \\ With plates $104(1)-110$ (7)
}

\begin{abstract}
Introduction
The genus Allocrangonyx was first described by Schellenberg (1936), who established this genus to include a single subterranean species (A. pellucidus) that had previously been described by Mackin (1935) but relegated to the genus Niphargus. Although Mackin (1935) placed his new species in Niphargus, he did so only after slightly modifying the original concept of this genus. Schellenberg (1936) did not agree with Mackin, however, and was able to clearly show why Allocrangonyx should be considered a distinct genus. Nevertheless, in a subsequent paper, Hubricht and Mackin (1940) gave a new locality record for $A$. pellucidus and continued to leave this species in Niphargus. Hubricht (1943), however, in giving further locality records for A. pellucidus, followed Schellenberg and recognized the genus Allocrangonyx.

During a current revision of the North American genera of the Crangonyx group of the family Gammaridae, I have had the opportunity to examine material pertinent to Allocrangonyx, and as a result of this study an undescribed species from two caves in central Missouri has been revealed and is described herein. Because of the singular importance of A.pellucidus as the type species of the genus and because of the new data obtained from additional collections and critical re-evaluation of older material, I have also found it necessary to give a partial redescription of this species. Moreover, in light of the newly obtained data, and in order to facilitate a critical comparison of Allocrangonyx with other potentially related North American and European amphipod genera, a diagnostic redescription of Allocrangonyx has been prepared.
\end{abstract}

1) Dept. of Biology, East Tennessee State Univ., Johnson City, Tenn. 37601

2) Present address of the author: Dept. of Biology, Old Dominion College, Norfolk, Virginia 23508. 
Acknowledgments. - I am particularly grateful to Mr. Leslie Hubricht of Meridian, Mississippi, who allowed me to examine his large collection of Allocrangonyx (which was recently deposited in the United States National Museum). I would also like to thank Dr. Richard C. Harrel of La Mar Institute of Technology, for lending me pertinent collections from caves in Oklahoma; and Professor Roger Husson of Dijon University, France, and Dr. Milan Straskraba of the Hydrobiological Laboratories, Prague, Czechoslovakia, for donating to my collections several species of European Niphargus which proved valuable in making critical comparisons between this genus and Allocrangonyx. Russell M. Norton of Yale University, Stewart B. Peck of Harvard University, and George E. Titcomb of Norris, Tennessee, assisted me in the field work of 1964 and their help is appreciated.

\section{Genue Allocrangonyx Schellenberg}

Allocrangonyx Schellenberg, 1936, p. 33 (Type species by original designation, Niphargus pellucidus Mackin 1935).

Diagnosis. - Without eyes or pigment; known only from subterranean waters (mostly caves). Size of sexually mature adults ranging from about $14.00 \mathrm{~mm}$ to $22.00 \mathrm{~mm}$. Antenna 1 longer than antenna 2, ranging in length from 45 to 85 percent as long as body; segment 1 of peduncle with 2 stets of small spines on ventral margin; accessory flagellum short, 2-segmented. Antenna 2: peduncular segment 4 a little longer than segment 5, with several sets of small spines on inner margin. Interantennal lobes rounded anteriorly. Mandible: incisor, lacina mobilis, and molar well developed; palpal segment 1 short, without setae; palpal segments 2 and 3 subequal in length, setose; segment 3 with a number of long lateral and apical setae. Maxilla 1: inner plate small, with 1 long, lightly plumose seta apically; outer plate much larger, with 9 slightly curved spines on apex. Maxilla 2: inner plate about one-half as large as outer plate, with a cluster of apical setae only; outer plate broader distally than proximally, apical margin uneven (concave), with 2 distinct sets of unequal setae, the outer set with several long, plumose setae, the inner set with smaller and none plumose setae. Maxilliped: inner plate small, armed apically with several slender spines; outer plate long, reaching well beyond apex of first segment of palp, with a row of blade-like spines on inner margin and several long, slender spines apically; palpal segment 2 the longest; nail of fourth palpal segment slender. Upper lip broadest distally. Lower lip: outer lobes much broader proximally than distally; inner lobes about one-half as large as outer lobes, well developed.

Gnathopod 1: propod subquadrate, palmar margin with a double row of tiny unequal spine teeth, the outer ones spinate, the inner ones distally notched; posterior angle defined by several larger spines; posterior margin 
long, with numerous setae. Gnathopod 2: propod much larger, subquadrate, palmar margin long, oblique, armed similar to first propod, but with more spines. Pereopods 3 and 4 subequal but coxal plate of 4 a little broader than that of 3 . Pereopod 7 more than 50 percent longer than body, a little longer than pereopod 6, substantially longer than pereopod 5. Dactyls of pereopods 6 and 7 (and sometimes 5) with ventral spines. Coxal gill on pereopod 2 (second gnathopod) large, with 2 unequal lobes; coxal gills of pereopods 3-6 smaller, oval to suboval. Sternal processes absent.

Abdominal side plates not produced posteriorly; posterior margins gently convex, with setae; posterior corners not acute, small and rounded; ventral margins without spines. Pleopods: inner rami longer than outer rami, longer than peduncles; peduncle of pleopod 2 longer than peduncles of pleopods 1 and $3 ; 2$ to 3 (usually 2) coupling hooks on inner distal margin of each peduncle. Uronites free, not fused; second with 1 pair of very small dorsolateral spines distally. Uropod 3 elongate, biramous; inner ramus very small; outer ramus well developed, 2-segmented, first segment long, second segment tiny to vestigial. First segment of outer ramus of third uropod with secondary segments in mature males. Telson broader than long, deeply clefted, armed with spines on each apical lobe.

Affinities. - Although assigned to the Crangonyx group by Schellenberg (1936), Allocrangonyx shares few morphological affinities with this group, and on this basis it cannot be retained there (Holsinger, 1967). The presence of distally notched spine teeth on the propod palmar margins of the gnathopods, and the structure of the telson in Allocrangonyx generally correspond to those found in the North American genera of the Crangonyx group, but aside from these characters, plus those shared by both Crangonyx group genera and the European genus Niphargus (e. g., reduced accessory flagellum of first antenna and general similarity in abdominal side plates), there is little resemblance between Allocrangonyx and the Crangonyx group genera.

On the contrary, Allocrangonyx appears to be more closely allied with Niphargus than with any of the North American amphipod genera, and it is of biogeographic interest to consider the similarities and differences between these two geographically separated genera in some detail. Their similarites can be summarized as follows: (1) overall structure of the mouthparts, especially of the first maxilla, maxilliped, and lower lip; (2) shape of the propod of the first gnathopod and possibly the second (cf., Niphargus dobrogicus Dancău, 1964); (3) presence of spines on the middorsal margin of the pereopod dactyls (but only in some species of Niphargus - see Cărăusu et al., 1955); (4) absence of sternal processes (or Sternalkiemen); (5) structure of the coxal gills, excepting the first pair in Allocrangonyx; (6) presence of dorsolateral spines on some of the uronites; and (7) the elongate and 2-segmented outer ramus of the third uropod. 
Allocrangonyx, however, differs from Niphargus in the following ways: (1) arrangement of setae on the third palpal segment of the mandible; (2) presence of non-serrate, apical spines on the outer plate of the first maxilla; (3) shape and setation of the apex of the outer plate of the second maxilla; (4) presence of tiny, distally notched spine teeth on the inner palmar margin of the gnathopodal propods; (5) presence of spines on the ventral margins of the dactyls of the last two or three pereopods; (6) presence of large, bi-lobed coxal gills of the second gnathopod; (7) secondary segmentation of the outer ramus of the third uropod in mature males and the reduction in size of the second segment of this structure in both sexes; and (8) form of the telson which is generally shorter and less deeply cleft.

Despite the similarities and differences between Allocrangonyx and Niphargus, the former genus embodies a combination of characters which is apparently unique in the Gammaridae. This diagnostic combination can be delineated as follows: (1) nine non-serrate, apical spines on the outer plate of the first maxilla; (2) two types of apical setae on the distally expanded outer plate of the second maxilla (also a characteristic of Pseudoniphargus africanus Chevreux, 1901); (3) one pair of large, bi-lobed, coxal gills on the second gnathopods; (4) both distally notched and spinate spine teeth on the palmar margins of the gnathopodal propods; (5) spine clusters on the ventral margins of the dactyls of pereopods 5,6, and 7; and (6) secondary segments in the outer ramus of the third uropod of mature males.

Following the earlier practices of Schellenberg (1936) and Ruffo (1956) (and see also Vandel, 1964) to assign various subterranean genera to groups (or phyletic lineages?) within the family Gammaridae, the Allocrangonyx group is herein designated to accomodate the single, rather unique genus Allocrangonyx. This new group can be distinguished by the diagnostic combination of the six characters given above.

\section{Allocrangonyx pellucidus (Mackin)}

(Figures 1, 2, 3)

Niphargus pellucidus Mackin, 1935, pp. 41-51, pl. 11 (Type locality: Bird's Mill Spring in southern Pontotoc Co., Oklahoma). - Hubricht and Mackin, 1940, p. 194. - Mackin, 1941, p. 29.

Allocrangonyx pellucidus (Mackin). - Schellenberg, 1936, p. 33. - Hubricht, 1943, p. 687 (in part). - Hubricht, 1950, p. 16 (in part). - Pennak, 1953, pp. 443-444, fig. 276 h, j, k. - Barnard, 1958, p. 43. - Hubricht, 1959, p. 877 (in part). - Nicholas, 1960a, pp. 126-127 (in part.). - Harrel, 1960, p. 31. - Harrel 1963, p. 130. Not Nicholas, 1960b, pp. 30-32.

Material Examined. - Oкцанома - Pontotoc Co.: Bird's Mill Spring (type locality), 15 paratypes (U. S. N. M. 137144), J. G. Mackin, 12 Nov. 1930; Coal Cave, R. C. Harrel, 2 June 1965 (Harrel Coll.); Murray Co.: 
seep, $482 \mathrm{~m}$ northwest of Turner Falls, L. Hubricht and J. G. Mackin, 11 May 1940 (U. S. N. M. Coll); small spring, $402 \mathrm{~m}$ northwest of Turner Falls, L. Hubricht, 23 Apr. 1936 (U. S. N. M. Coll.); Wildwoman Cave, R. C. Harrel, 28 Feb. and 10 July 1959 (Harrel Coll.); Bitter Enders Cave, J. R. Holsinger and R. M. Norton, 24 June 1964 (Holsinger Coll.).

Diagnosis. - Large cavernicolous species easily distinguished from A. hubrichti, new species (below), to which it is closely allied morphologically, by larger size of sexually mature adults, proportionately shorter first antenna and seventh pereopod, smaller and much less spinose dactyls of pereopods 6 and 7, fewer spines on uropods 1 and 2, three to four fewer secondary segments in outer ramus of third uropod of mature males, and having more apical spines on telson. Largest male, $21.75 \mathrm{~mm}$; largest female, $18.00 \mathrm{~mm}$.

Corresponding to the description of Mackin (1935) with the following addtions and modifications:

Antenna 1 varying from 45 to 65 percent as long as body, 40 to 60 percent longer than antenna 2; primary flagellum with up to 32 segments. Antenna 2: peduncular segment 4 with several small, lateral spines on inner margin; flagellum with up to 16 segments. Gnathopod 1: propod subquadrate, plamar margin slightly convex, armed with a double row of 18 to 20 tiny spine teeth, the outer ones spinate, the inner ones distally notched; posterior angle with 6 large but unequal spines (mostly notched) on outside, 2 notched spines on inside; posterior margin long, nearly straight except proximally, with 10 sets of setae; inferior lateral setae in 2 transverse rows, mostly singly inserted; superior lateral setae in 1 transverse row, in 4 sets of 5 to 6 setae each; dactyl nail slightly curved, rather slender. Segment 5 of first gnathopod nearly as long as combined lengths of segments 3 and 4, posterior margin heavily setose. First coxal plate a little longer than broad; distal margin long, convex, armed with 16 to 17 setae. Gnathopod 2: propod nearly twice as large as that of first gnathopod; palmar margin long, oblique, gently convex, armed with an irregular double row 30 or more tiny spine teeth, the outer ones spinate, the inner ones with tiny distal notches; posterior angle well developed, offset from palmar margin, with 2 long, unequal spines on outside, 1 smaller spine on inside; posterior margin straight distally, convex proximally, with about 7 sets of setae; inferior lateral setae in transverse row, in sets of 2's, 3's, and 5's; superior lateral setae in transverse row, in 7 sets, ranging from 2 to 8 setae per set; dactyl long and curved, nail rather blunt. Segment 5 of second gnathopod not as long proportionately as that of first gnathopod. Coxal plates of pereopods $2-4$ a little longer than broad, marginally with 8 to 11 setae. Pereopod 7 about 55 percent as long as body, a little longer than pereopod 6, 40 to 45 
percent longer than pereopod 5. Bases of pereopods 5-7 a little broader proximally than distally, posterior margins gently convex, distoposterior lobes distinct, bluntly rounded. Dactyls of pereopods $5-7,25$ to 30 percent as long as corresponding propods; dactyl of pereopod 7 with 2 sets of spines distally on ventral margin; that of pereopod 6 with 1 set of spines distally; dactyl of pereopod 5 without ventral marginal spines. Brood plates very small, narrow, not extending as far distally as end of second segment of pereopods.

Abdominal side plates: posterior margins gently convex, armed with 4 to 7 short setae; posterior corners small, rounded; ventral margins without spines. Pleopods: inner rami a little longer than outer rami, 45 to 50 percent longer than peduncle in pleopod 1,20 to 25 percent longer than peduncles in pleopods 2 and 3. Male pleopods; outer ramus of first with up to 21 segments, second with up to 20 segments, third with up to 17 segments; inner rami with 21, 19, and 16 segments in pleopods 1, 2, and 3, respectively. Female pleopods with a few less segments in both outer and inner rami. Peduncles of pleopods with 2 to 3 coupling hooks (usually 2 ) distally on inner margins. Uropod 1: inner ramus a little longer than outer ramus, 45 to 50 percent as long as peduncle, armed with 7 spines; outer ramus with 10 to 11 spines; peduncle with 10 to 11 spines. Uropod 2: inner ramus a little longer than peduncle, about 20 percent longer than outer ramus, armed with 10 or 11 spines; outer ramus with about 8 spines; peduncle with 6 to 8 spines. Uropod 3 up to 30 percent as long as body in mature males, up to 20 percent as long as body in mature females. Uropod 3 of male: inner ramus small, scale like, less than 50 percent as long as peduncle, with 1 apical spine; peduncle longer than broad, armed with several lateral marginal spines and a row of distal marginal spines; outer ramus elongate, between 6 and 7 times as long as peduncle in mature males, armed laterally with numerous spine clusters and a few plumose setae, with a rudimentary second segment and usually 5 secondary segments (rarely 6) in largest males. Uropod 3 of female: outer ramus of mature female between 3 and 4 times as long as peduncle, with a vestigial second segment, but lacking secondary segmentation. Telson broader than long, apical margin more deeply cleft in males than in females; armed apically with 6 to 7 unequal spines on each lobe in both sexes.

Variation. - The extreme sexual dimorphism exhibited by the unusual development of the third uropod of the male has already been noted. Figure 3 illustrates a comparison of this structure in both males and females of progressively larger sized animals from the same population sample. In both sexes the second segment of the outer ramus rapidly decreases in proportion to an increase in the size of the first segment. Finally, in older 
animals the second segment is barely discernible and sometimes almost impossible to detect at all.

Figure 3 also illustrates the manner in which the outer ramus of the male third uropod differentiates into secondary segments as its length concomitantly increases with the progressive increase in the overall size of the animal. In addition to this differentiation, there is also a positive allometric increase in the length of the outer ramus in relation to the length of the peduncle and to the length of the body. The former relationship is illustrated in Figure 3 ; the latter, calculated to be approximately 9 percent, was based on measurements of individuals ranging in body length from $14.25 \mathrm{~mm}$ to $20.25 \mathrm{~mm}$. In contrast to the male, there appears to be little or no allometry in the growth of the outer ramus of the third uropod of the female.

Distribution and Ecology. - This species is presently known from three caves, two springs, and one seep located in the Arbuckle Mountains of south-central Oklahoma. Most of these localities occur in Ordovician limestones of the Arbuckle uplift. A. pellucidus occupies a range of approximately $80 \mathrm{~km}$, extending from southwestern Murray County northeastward to southern Pontotoc County.

The largest collections of $A$. pellucidus have been made from a seep near Turner Falls (179 specimens) and from pools in Wildwoman Cave (see Harrel, 1960, 1963) which is located about $13 \mathrm{~km}$ to the southwest. Harrel (1963 and in litt.) reported two ovigerous females from February collections made in Wildwoman Cave and several more from a January collection made in Coal Cave in Pontotoc County. But, since this material was not included in the part of the Harrel collection that I examined, the approximate clutch size for this species could not be determined. Collections from the months of April, May, June, and November did not contain ovigerous females.

Although A.pellucidus has been taken from springs, it is probably largely a cavernicolous species. Many of the springs in the Arbuckles are fed directly from caves and solution channels and could easily afford exit to the surface for subterranean amphipods during certain times of the year. Furthermore, this species is very common in Wildwoman Cave (Harrel, 1960) and its large size would almost certainly eliminate it from interstitial habitats. In Bitter Enders Cave, Murray County, four specimens of $A$. pellucidus were collected from submerged wood in rock basin pools, ranging from $15 \mathrm{~cm}$ to $30 \mathrm{~cm}$ in depth. Troglobitic isopods (Asellus tridentatus - det. by H. R. Steeves, III) were also collected from the same pools.

Remarks. - As a result of the present study, the range of A.pellucidus is more closely circumscribed and should be restricted to groundwater habitats of the Arbuckle Mountains of south-central Oklahoma. Although Hubricht $(1943,1959)$ included material from central Missouri (Phelps and 
Pulaski Counties) within the range of A.pellucidus, my examination revealed that that these populations are morphologically distinct and belong to the new species described below.

\section{Allocrangonyx hubrichti, new species}

(Figures 4, 5, 6)

Allocrangonyx pellucidus (Mackin). - Hubricht, 1943, p. 687 (in part). - Hubricht, 1950, p. 16 (in part). - Hubricht, 1959, p. 877 (in part). - Nicholas, 1960 a, pp. $126-127$ (in part). - Nicholas, 1960 b, pp. $30-32$.

Material Examined. - Missouri - Phelps Co.: Saltpeter Cave, $11.2 \mathrm{~km}$ north of Newburg, holotype male, allotype female, and 5 paratypes, L. Hubricht, 7 Oct. 1939; Pulaski Co.: Maxey Cave (= Inca Cave) 2 paratypes, L. Hubricht, 10 May 1942. The holotype and allotype (partially on slide mounts), and paratypes are deposited in the U. S. National Museum.

Diagnosis. - Relatively large cavernicolous species readily distinguished from $A$. pellucidus by smaller size of mature adults, proportionately longer first antenna, proportionately longer seventh pereopod which is 65 to 70 percent as long as the body, mid-dorsal spines on dactyls of pereopods $3-7$, larger and more spinose dactyls of pereopods 6 and 7, proportionately longer outer ramus of third uropod (which has up to 9 secondary segments in the mature male), more deeply cleft telson in males, and having 4 to 6 fewer apical spines on telson.

Male (holotype). - Antenna 1 up to 70 percent as long as body, about 50 percent longer than antenna 2 ; primary flagellum with up to 35 segments; accessory flagellum short, not as long as first primary flagellar segment. Antenna 2: segment 4 of peduncle a little longer than fifth segment, with several sets of lateral spines on inner margin; flagellum with up to 15 segments. Mandibular palpal segments 2 and 3 subequal in length; segment 2 with about 18 inner marginal setae; segment 3 with a number of long, inner marginal, lateral, and apical setae. Maxilla 1, inner plate with 1 plumose, apical seta; outer plate with up to 9 curved spines apically. Maxilla 2: inner plate about one-half as large as outer plate, with about 15 slender apical setae; outer plate broadest distally, apical margin slightly concave, with 2 irregular sets of setae, the outer set having fewer and longer setae than the inner set. Maxilliped: outer plate long, reaching about one-half the distance along the second segment of palp, inner margin with a row of about 12 spines, apex with several long setae and about 3 slender spines; inner plate much shorter and more narrow than outer plate, apically with about 4 
slender spines. Lower lip: outer lobes much broader proximally than distally; inner lobes well developed but only about one-half as large as outer lobes.

Gnathopod 1: propod similar to that described for A. pellucidus but with a few less posterior marginal and lateral setae; coxal plate with only 9 marginal setae. Gnathopod 2: propod generally similar to that of $\mathrm{A}$. pellucidus, but a little less large in proportion to first propod and with a few less lateral setae. Coxal gill of second gnathopod broadly expanded, with 2 unequal lobes about as shown. Coxal plates of pereopods 2 and 3 a little longer than broad, with 6 to 7 marginal setae. Coxal plate of pereopod 4 about as broad as long, with 8 marginal setae. Pereopod 7 a little longer than pereopod 6 , about 45 percent longer than pereopod 5 . Bases of pereopods 5-7 not much broader proximally than distally, broadest medially, distoposterior lobes well developed, broadly rounded. Dactyls of pereopods 6 and 7 large, 40 to 45 percent as long as corresponding propods, with 4 sets of spines and 2 or 3 plumose setae on ventral margins, 3 to 4 sets of spines on dorsal margins.

Abdominal side plates and pleopods about like those described for $A$. pellucidus. Uropod 1 : inner ramus about 30 percent longer than outer ramus, 60 percent as long as peduncle, armed with about 8 spines; outer ramus with about 12 spines; peduncle with 14 spines. Uropod 2: inner ramus about 30 percent longer than outer ramus, up to 20 percent longer than peduncle, armed with 11 spines; outer ramus with 11 spines; peduncle with 7 spines. Uropod 3 up to 45 percent as long as body; peduncle longer than broad, with a few lateral and distal spines; inner ramus small, with 2 apical spines; outer ramus up to 8 times as long as peduncle, with a tiny vestigial (?) second segment and 9 secondary segments, armed laterally with numerous sets of spines and on first secondary segment with a number of long, plumose setae. Telson broader than long, apical margin cleft about one-fourth the distance to base, apical lobes with 4 unequal spines each.

Female (allotype). - Differing from the male in a few details as follows: Antenna 1, 80 to 85 percent as long as body, about 40 percent longer than antenna 2, with up to 34 segments in primary flagellum. Antenna 2 with up to 14 segments in flagellum. Brood plates small and narrow, about like those described for A. pellucidus. Uropod 3 shorter proportionately, only about 30 percent as long as body; outer ramus less than 4 times as long as peduncle, with a vestigial second segment and no secondary segmentation.

Variation. - The marked sexual dimorphism of the third uropod of the male noted for A. pellucidus is also present in A. hubrichti. In the male of this species, however, the positive allometric relationship of the length of the outer ramus to the length of the peduncle and to the body is even stronger. 
In older males the third uropod may be up to 45 percent as long as the body. Concomitantly, the outer ramus of the male differentiates into as many as nine secondary segments, as opposed to only five (or rarely six) in A. pellucidus.

Type Locality. - The type series was collected by Leslie Hubricht from a stream in Saltpeter Cave, $11.2 \mathrm{~km}$ north of Newburg, Pulaski Co., Missouri The physical features of this cave were described by Bretz (1956).

Distribution and Ecology. - A. hubrichti is presently known from the small streams of two caves in the Ozark Plateau region (Salem Plateau section) of central Missouri. Both caves are developed in Ordovician dolomites, occur in the Gasconade River drainage, and are located about $38.4 \mathrm{~km}$ apart.

Among the seven specimens collected from the type locality by Hubricht (October collection) was a single ovigerous female $(14.50 \mathrm{~mm})$ with 5 embryos in the brood pouch. The embryos averaged $1.15 \mathrm{~mm}$ in diameter.

Remarks. - It is a pleasure to name this species in honor of Mr. Leslie Hubricht, whose observations and collections of freshwater invertebrates have added immensely to the knowledge of aquatic biology in North America.

\section{Discussion}

As presently delimited, the ranges of the two component species of Allocrangonyx are spatially isolated by a distance barrier of approximately $520 \mathrm{~km}$. The populations of A. hubrichti appear to be confined to caves developed in the Ordovician limestones (and dolomites) of the central Ozark Plateau region (specifically the Salem Plateau), while populations of A. pellucidus are apparently confined to caves and related solution channels developed in the Ordovician limestones of the Arbuckle Mountains of south-central Oklahoma (see fig. 7 for distribution). The large size of adults and their almost exclusive association with cave waters strongly indicate that both species of Allocrangonyx are largely restricted to caves and solution channels, and that these species do not normally occur in superficial groundwater and interstitial biotopes as do many other subterranean amphipods (viz., Stygonectes alabamensis, S. tenuis, $S$. allegheniensis, and Apocrangonyx subtilis). If species of Allocrangonyx are confined to cave habitats as implied by distributional data, their ranges would be physically isolated by: (1) stratigraphic differences between the exposures of cavernous limestones in the Arbuckles and the Ozarks, and (2) intervention of noncavernous bedrock (Permian age) that makes up the area between the western edge of the Ozark Plateau and the Arbuckles. 
Although two other species of subterranean crustaceans - Asellus tridentatus (Hungerford) and Stygonectes alabamensis (Stout) - have been recorded from both the Arbuckles and the Ozarks (Hubricht, 1950; Holsinger, 1967; Steeves, in litt.), these species can presumably undergo at least limited dispersal between these two regions via subsurface routes. Both species have been taken from habitats fed by superficial groundwaters and neither species is apparently restricted to cave waters. In recent years, as additional distributional data have become available on subterranean crustaceans, it has become increasingly obvious that the problems inherent in the dispersal of cavernicolous amphipod species (i. e., like species of Allocrangony $x$ for example) are different from those inherent in the dispersal of phreatobitic and interstitial species (e. g., such as those species of Stygonectes mentioned above). In a recent paper (Holsinger, 1967) the possible dispersal mechanisms of some of the more widely ranging species of Stygonectes were discussed, and it was generally concluded that these species are by no means restricted to cave habitats but can occupy almost any available groundwater habitat within their range.

The close morphological alliance of $A$. pellucidus and $A$. hubrichti suggests that both of these species may have been derived from a single ancestral species. The question of how long the gene pools of these two species have been isolated from each other, and the manner in which this isolation has been attained, however, can be answered only approximately. Did contemporary species of this genus diverge from an epigean or semi-epigean ancestor or did they diverge from an ancestral form already of subterranean facies? Such questions may never be conclusively answered, although at least partial solutions seem to be attainable on the basis of present evidence.

Allocrangonyx, like Stygonectes, Stygobromus, and Apocrangonyx, is represented by species which are exclusively depigmented, eyeless hypogean forms. Even remotely related epigean species that might be regarded as relicts of ancestors of these groups are unknown to date. But on the contrary, two other genera of freshwater amphipods - Crangonyx and Gammarus are represented both in epigean and subterranean waters by species that are morphologically (and genetically?) closely related and vary from eyed, pigmented forms to those without these features. Because of this fact, plus some other considerations discussed elsewhere (Holsinger, 1967), I have been inclined to regard several of the exclusively subterranean genera (especially Stygonectes) as having been of subterranean facies since the onset of their invasion of the freshwater environment. For the same reason (i. e., lack of epigean ancestors and/or surface congeners) I am now somewhat inclined to regard freshwater Allocrangonyx as having originated in a similar manner, although admittedly, at least one alternative possibility (see below) cannot 
be ruled out. Perhaps the best place to search for ancestral relicts of these subterranean genera (providing they are not extinct) would be in marine or brackish waters (cf., marine Eriopisa vis-à-vis freshwater Niphargus)!

If one considers both historic geology and the present distributional pattern of Allocrangonyx, it is not inconceivable to look to the Cretaceous period as one of the most likely times for invasion and colonization of freshwaters by an ancestral stock. During this period much of western North America was covered by an extensive inland sea (Kummel, 1961; Schuchert and Dunbar, 1950), and at the height of this embayment a part of the Arbuckles would have been only a few kilometers from shallow marine water. Similarly, the central Ozarks, although farther inland, would haven been only about $250 \mathrm{~km}$. from marine waters

The colonization of freshwater by early Allocrangonyx stock may well have in the from of an exploitation of groundwater habitats in general, resulting ultimately in a generic range which extended from southern Oklahoma northeastward to central Missouri. Eventually, as the climate became more unstable and progressively drier throughout the southwestern United States during the late Cenozoic (Schuchert and Dunbar, 1950; Hibbard, 1960), many populations of subterranean amphipods, especially those of larger species which could not maintain themselves in interstitial and superficial groundwater habitats, were probably forced into deeper and more permanent groundwater habitats (such as those provided by caves) in order to survive. Undoubtedly, drier conditions during glacial minima would have resulted in lower and less stable groundwater tables. Caves on the other hand often contain permanent streams even in very dry regions. During a prolonged drought on the surface, caves could easily serve as refugia for groundwater species, which, under normal conditions, might survive in more superficial habitats nearer the surface (e. g., water filled crevices, fissures, seeps, etc.). Since much of the area between the Ozarks and the Arbuckles is floored by non-cavernous bedrock, the invasion and subsequent colonization of caves would have occurred only in the cavernous regions now occupied by species of Allocrangonyx. Theoretically, this colonization would have led to isolation through physical separation of gene pools and subsequently to speciation.

Even if one takes a slightly opposite view and postulates an epigean ancestor for the present subterranean species of Allocrangonyx, the possibility that progressively drier climatic conditions during the late Cenozoic was one of the main factors that caused ancestral populations to seek more permanent groundwater biotopes for survival is a tenable one. During extreme droughts, virtually all surface water habitats might have dried up, leaving only permanent cave streams as suitable biotopes. For presumptive evidence 
that hypothetical epigean populations of Allocrangonyx might have been preadapted to a groundwater environment, one can look at parallels found in the ecology of many contemporary epigean species of Crangonyx and Gammarus. In the humid regions of the eastern United States, these species are usually inhabitants of shaded areas in cold water springs or spring-fed streams. In some areas species of Crangonyx and Gammarus are represented by populations both inside and outside of caves.

The majority of epigean, freshwater species of Gammaridae are apparently both cold stenothermic and photonegative and are therefore, to a large extent, preadapted to groundwater conditions. Thus, whether one seeks hypogean or epigean ancestors for contemporary subterranean amphipods (such as Allocrangonyx), there appear to be few major ecological deterrents to the formulation of workable hypotheses along the lines suggested above.

décembre 1967

\section{SUMMARY}

The systematics of the North American, subterranean amphipod genus Allocrangonyx are revised and two species are recognized - A. pellucidus (Mackin) and $A$. hubrichti, new species. Allocrangonyx is critically compared with the European genus Niphargus and several endemic North American genera of the Crangonyx group. Because of its unique morphological position, Allocrangonyx is removed from the Crangonyx group and placed in the newly designated Allocrangonyx group. Some factors believed to have influenced speciation within the genus are discurssed in some detail.

\section{ZUSAMMENFASSUNG}

Die Systematik der nordamerikanischen unterirdischen Amphipod-Gattung Allocrangonyx wird bearbeitet. Zwei Spezies werden anerkannt: A. pellucidus (Mackin), und eine neue Spezies, A. hubrichti. Allocrangonyx wird mit der europäischen Gattung Niphargus und einigen endemisch nordamerikanischen Gattungen der Crangonyx Gruppe kritisch verglichen. Wegen der eigenartigen morphologischen Stellung wird Allocrangonyx aus der Crangonyx Gruppe herausgenommen und in die neugeformte Allocrangonyx Gruppe eingereiht. Einige Faktoren, deren Einfluß auf die Evolution binnen dieses Genus vorausgesetzt werden kann, werden ausführlich diskutiert.

\section{REFERENCES}

BARNARD, J. L. (1958) - Index to the families, genera, and species of the gammaridean Amphipoda (Crustacea). Allan Hancock Foundation, Publ. 19, 145 pp.

Bretz, J. H. (1956) - Caves of Missouri. Missouri Div. Geol. Surv. and Water Resources, vol. 39, 2nd ser., $491 \mathrm{pp}$.

Căräueu, S., E. Dobreanu, and C. Manolache (1955) - Amphipoda. Forme salmastre și de apă dulce. Fauna Republicii Populare Romine. Crustacea. Vol. 4, fasc. 4, 407 pp.

Chevreux, E. (1901) - Amphipodes des eaux souterraines de France et D'Algérie. Bull. Soc. Zool. France, vol. 26, pp. 211-216.

DANCÁU, D. (1964) - Noi contribuții la studiul amfipodelor subterane Niphargus dobrogicus n. sp. Lucr. Inst. de Speol. "Emil Racovită”, vol. 3, pp. 397-403. 
Harrel, R. (1960) - A preliminary report on the invertebrate animals of Wild Woman Cave. Proc. Oklahoma Acad. Sci., vol. 40, pp. 29 - 34.

- (1963) - Further notes on invertebrate animals of Wild Woman Cave, Murray County, Oklahoma. Proc. Oklahoma Acad. Sci., vol. 43, pp. 129-131.

Hibbard, C. W. (1960) - An interpretation of Pliocene and Pleistocene climates in North America: President's address to the Michigan Acad. Sci., Arts, and Letters. In Michigan Acad. Rep. for $1950-1960$, pp. 5-30.

Holsinger, J. R. (1967) - Systematics, speciation, and distribution of the subterranean amphipod genus Stygonectes (Gammaridae). U. S. Nat. Mus. Bull. $259,176 \mathrm{pp}$.

Hubricht, L. (1943) - Studies on the Nearctic freshwater Amphipoda, III : Notes on the freshwater Amphipoda of eastern United States with description of ten new species. Amer. Midl. Nat., vol. 29, pp. 683-712.

- (1950) - The invertebrate fauna of Ozark caves. Bull. Nat. Speleological Soc., vol. 12 , pp. $16-17$.

- (1959) - Malacostraca (Amphipoda), pp. 876-878. In W. T. EDMONDson (ed.), Ward and Whipple's freshwater biology. John Wiley and Sons, Inc., New York.

Hubricht, L. and J. G. MACKIN (1940) - Descriptions of nine new species of fresh-water amphipod crustaceans with notes and new localities for other species. Amer. Midl. Nat., vol. 23, pp. 187-218.

Kummel, B. (1961) - History of the earth. W. H. Freeman and Co., San Francisco. $610 \mathrm{pp}$.

MACKIN, J. G. (1935) - Studies on the Crustacea of Oklahoma, III: Subterranean amphipods of the genera Niphargus and Boruta. Trans. Amer. Microscop. Soc., vol. 54 , pp. $41-51$, pl. 11 .

- (1941) - A key to the species of Amphipoda of Oklahoma. Proc. Oklahoma Acad. Sci., vol. 21, pp. 29-30.

Nicholas, B. G. (1960a) - Checklist of macroscopic troglobitic organisms of the United States. Amer. Midl. Nat., vol. 64, pp. 123-160.

- (1960 b) - Preliminary list of troglobites of Missouri. Missouri Speleology, vol. 2 , no. 2 , pp. $30-37$.

Pennak, R. W. (1953) - Fresh-water invertebrates of the United States. Ronald Press Co., New York. 769 pp.

RUFFo, S. (1956) - Lo stato attuale delle conoscenze sulla distribuzione geografica degli Anfipodi delle acque sotteranee europee e dei paesi mediterranei. Publ. Premier Congrès International de Spéléologie (Paris, 1953), vol. 3, sec. 3, pp. $13-37$.

SCHellenberG, A. (1936) - Die Amphipodengattungen um Crangonyx, ihre Verbreitung und ihre Arten. Mitteilung Zool. Mus., Berlin, vol. 22, pp. 31-43.

Schuchard, C. and C. O. Dunbar (1950) - Outlines of historical geology. John Wiley and Sons, Inc., New York. 291 pp.

VANDEL, A. (1964) - Biospéologie - La biologie des animaux cavernicoles. Gauthier-Villars Éditeur, Paris. 619 pp.

\section{EXPLANATION OF PLATES 104 (1)-110 (7)}

Plate 104 (1): Allocrangonyx pellucidus (Mackin). Male $(21.75 \mathrm{~mm})$, seep $482 \mathrm{~m}$ northwest of Turner Falls, Oklahoma: a, b, gnathopods 1, 2; c, coxal plate of pereopod $3 ; \mathrm{d}-\mathrm{g}$, pereopods $4,5,6,7$.

Plate 105 (2): Allocrangonyx. pellucidus (Mackin). Male $(21.75 \mathrm{~mm})$, seep $482 \mathrm{~m}$ northwest of Turner Falls, Oklahoma: a, abdominal side plates; b, right mandible; c, uropod 2; d, pleopod 1; e, telson; f, antenna 2. Female $(18.00 \mathrm{~mm})$, same locality: $\mathrm{g}$, telson.

Plate 106 (3): Allocrangonyx pellucidus (Mackin). Third uropods of females from seep, $482 \mathrm{~m}$ northwest of Turner Falls - uropods from specimens of the following sizes: a, $13.50 \mathrm{~mm}$; b, $14.00 \mathrm{~mm}$;, $15.75 \mathrm{~mm}$; d, $18.00 \mathrm{~mm}$. Third uropods of 
males from the same population - uropods from specimens of the following sizes: e, $6.70 \mathrm{~mm}$;, $8.50 \mathrm{~mm}$; g, $14.25 \mathrm{~mm}$; h, $15.50 \mathrm{~mm}$;, $17.25 \mathrm{~mm}$;, $20.25 \mathrm{~mm}$. All uropods drawn to same scale.

Plate 107 (4): Allocrangonyx hubrichti, new species. Male holotype $(15.00 \mathrm{~mm})$ : a, upper lip; b, lower lip; c, d, maxillae 1, 2; e, maxilliped; f, left mandible; g, dentate part of right mandible; h, bi-lobed coxal gill of gnathopod 2; i, tels on; $\mathrm{j}$, abdominal side plates; $\mathrm{k}$, coxal plate of pereopod $3 ; 1$, pereopod $4 ; \mathrm{m}$, n, uropods $1,2$.

Plate 108 (5): Allocrangonyx hubrichti, new species. Male holotype: a, antenna 2; b, c, gnathopods 1,2 .

Plate 109 (6): Allocrangonyx hubrichti, new species. Female allotype $(14.50 \mathrm{~mm})$ $\mathrm{a}, \mathrm{b}, \mathrm{c}$, pereopods $5,6,7 ; \mathrm{d}$, uropod 3 . Male holotype: e, antenna $1 ; \mathrm{f}$, uropod 3 . Plate 110 (7): Distribution of Allocrangonyx: stippled area marks the range of A. pellucidus and also the approximate extent of the Arbuckle Mountains; solid area marks the range of $A$. hubrichti. Broken line approximately indicates the maximum extent of marine embayment during the Cretaceous. Dotted line represents the boundary of the Ozark Plateau region. 


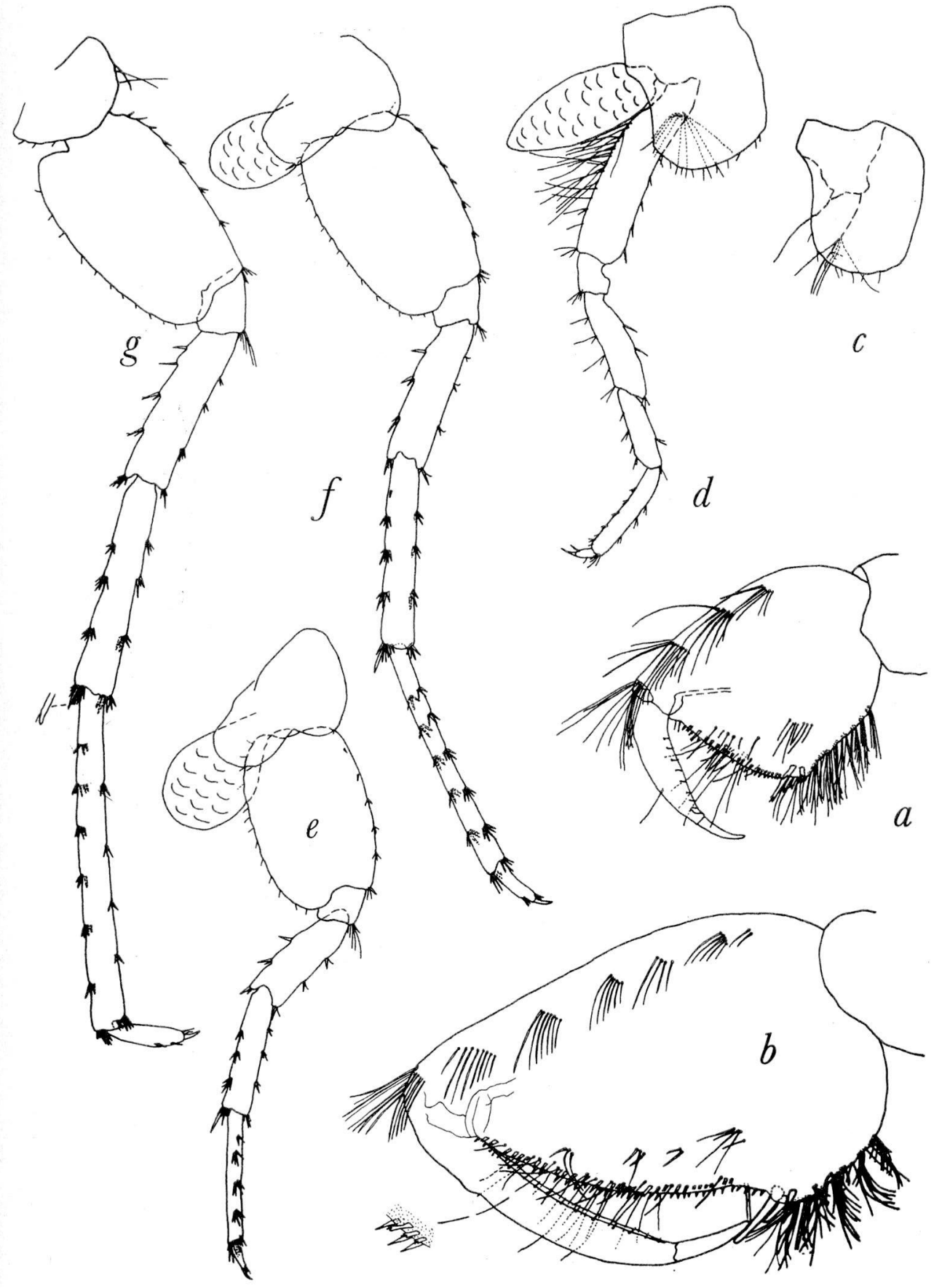








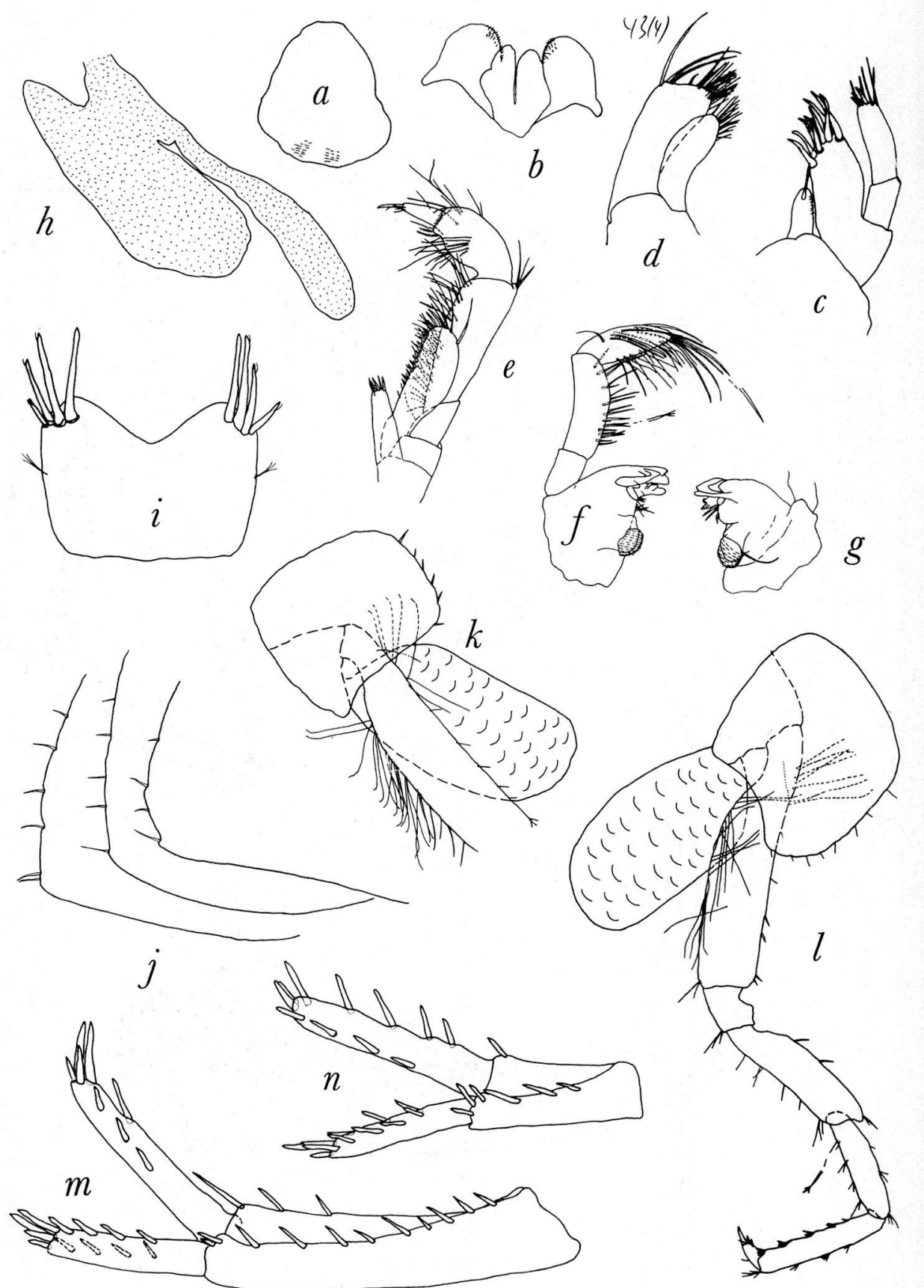





$\eta$ 







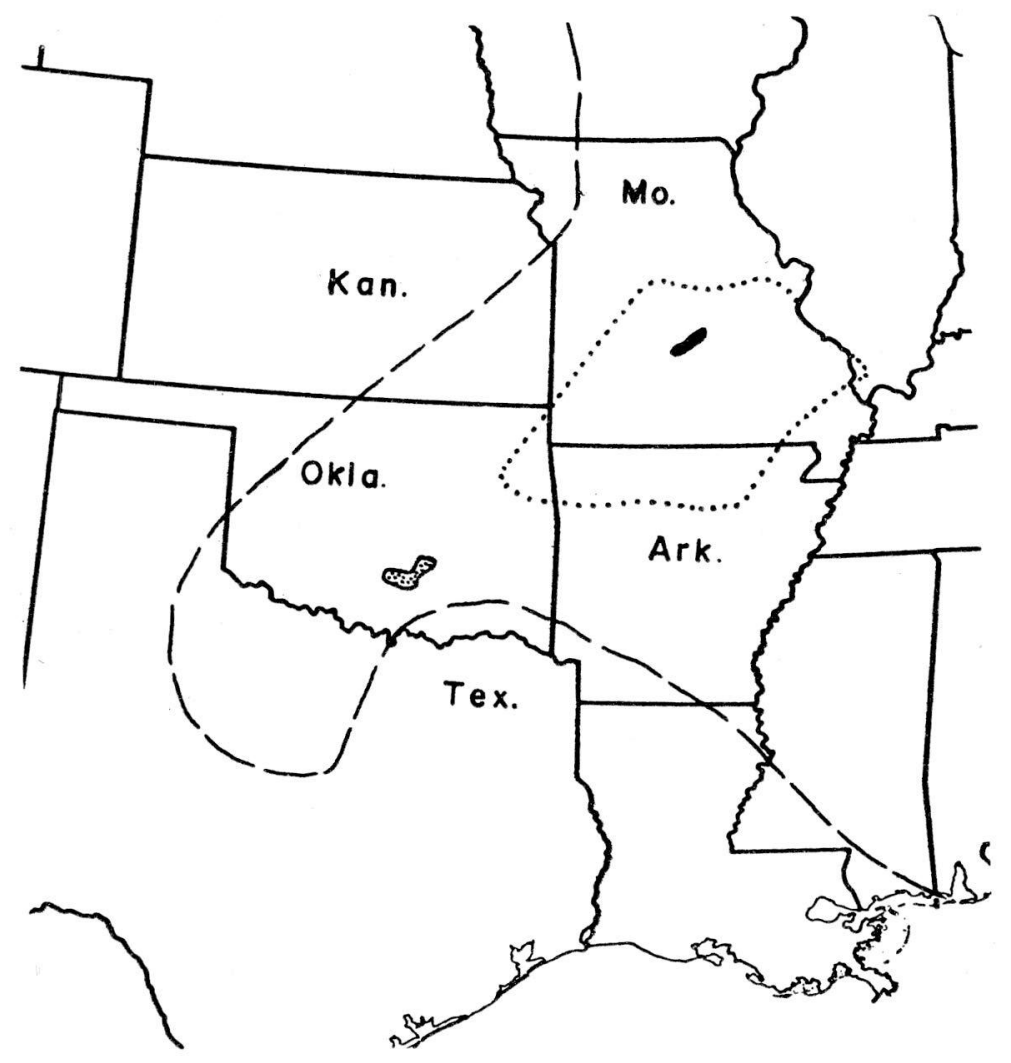

